\title{
MINIMUM WAGE AS ONE OF THE MAIN STATE SOCIAL GUARANTEES
}

\author{
Serhii Kivalov ${ }^{1}$ \\ Viktoriia Tarasenko ${ }^{2}$ \\ Svitlana Voloshyna ${ }^{3}$ \\ Rashyd Chanyshev ${ }^{4}$ \\ Oleksandr Shchukin ${ }^{5}$
}

\begin{abstract}
The definition, goals of the minimum wage, the criteria for its determination, the sphere of application of the system of setting the minimum wage, the procedure for its establishment, as well as regulation and implementation were analyzed in the article. Comparative legal analysis was carried out of the acts of national labor legislation for compliance with international and European standards, enshrined in conventions and recommendations of the International Labor Organization, Attention is drawn to the fact that Ukraine has not yet undertaken obligations under paragraph 1 of Art. 4 of the European Social
\end{abstract} Charter (revised).The essence and significance of the minimum wage as one of the main state social guarantees is revealed, taking into account changes and amendments, made by the Legislation of Ukraine. The ratio of the category "minimum wage" and the category "subsistence level set for ablebodied persons on January 1 of the calendar year" is determined.

Keywords: wages, minimum wages, state social guarantees, international standards, legislation of Ukraine..

\section{Introduction}

The current legislation of Ukraine refers minimum wage fixing to

Doctor of Legal Sciences, Professor, National University “Odessa Academy of Law”, Odessa, Ukraine ${ }^{1}$ Candidate of Legal Sciences, Associated Professor, National University "Odessa Academy of Law”, 2 Odessa, Ukraine Candidate of Legal Sciences, Associated Professor, National University “Odessa Academy of Law”, 3 Odessa, Ukraine Candidate of Legal Sciences, Associated Professor, National University "Odessa Academy of Law”, 4 Odessa, Ukraine Candidate of Legal Sciences, Associated Professor, National University "Odessa Academy of Law", 5 Odessa, Ukraine 
the sphere of state regulation of remuneration for work. In all developed countries of the world, the minimum wage is recognized as one of the main state social guarantees, and the legal regulation of its mechanism is carried out by international legal acts and acts of national legislation. The minimum wage is an important indicator of socioeconomic development of the state, the material well-being of its population. The current legislation of Ukraine provides for a mechanism of the minimum wage, which in modern conditions needs to be improved taking into account international and European standards and the positive legislative experience of foreign countries.

\section{Literature review}

Issues of legal regulation of the minimum wage were investigated in the scientific works. In particular Vegera (2014) and Derevyanko (2015) draw attention to the imperfection of the legislative definition of the minimum wage and the criteria for its determination, while offering an author's understanding of these categories. Derevyanko (2015) also reveals the role of the minimum wage as a guarantee in the field of labor relations. Theoretical and practical aspects of establishing the minimum wage as a way of state regulation of remuneration for labor in Ukraine are investigated in the dissertation for the degree of the Candidate of Legal Sciences of Vegera (2014). Dovbysh (2017) in her dissertation for the degree of the Candidate of Legal Sciences, explores the category of generally accepted international standards for the minimum wage fixing. The researcher also proves the need to develop and adopt the Law of Ukraine "On Minimum Wage" and formulates proposals for its structure and content.

The expressed views and proposals of these researchers on the mechanism of the minimum wage deserve support. At the same time, they need further development, taking into account changes and amendments to the current legislation, the draft Labor Code of Ukraine, which is being prepared for adoption in the second reading.

The aim of the article is to reveal the essence and significance of the minimum wage as one of the main state social guarantees, its relationship with the subsistence level as a basic state social standard. 


\section{Results}

Among the international legal acts, the ILO conventions and recommendations should be singled out first of all. Thus, the ILO Minimum Wage-Fixing Machinery Convention № 26 of 1928 (1) provides for the order of determination of the content and form of this procedure, as well as the methods of its implementation. ILO Minimum Wage Fixing Convention No. 131 of 1970 with special regard to developing countries (hereinafter referred to as the ILO Convention №131) (2) and ILO Minimum Wage Fixing Recommendation № 135 of 1970 with special regard to developing countries (hereinafter - ILO Recommendation №135) (3), establish the goals for the minimum wage fixing, criteria for its determination, the sphere of application of the system for setting the minimum wage, the procedure for the minimum wage fixing, its regulation, implementation.

Section I of ILO Recommendation №135 (3) sets out the goals for fixing the minimum wage. According to paragraph 1 of this section, minimum wage fixing should be one element of the policy, aimed at combating poverty and meeting the needs of all workers and their families. The main purpose of the minimum wage fixing should be the provision of employees with the necessary social protection (Borychenko et al., 2019) in relation to the minimum allowable wage levels (paragraph 2 of ILO Recommendation №135 (3).

Art. 3 of the ILO Convention №131 (2) and paragraph 3 of the ILO Recommendation №135 (3) set out the criteria that are taken into account while fixing the minimum wage level. It is envisaged that, among others, the following criteria should be taken into account (Popova et al., 2019): a) the needs of workers and their families; b) the general level of wages in the country; c) the cost of living and its changes; d) social payments; e) comparative standard of living of other social groups; f) economic factors, including the needs of economic development (Nazarova et al., 2020; Yankovyi et al., 2020), the level of labor productivity and the desirability of achieving and maintaining a high level of employment.

Part 1 of article 4 of the ILO Convention №131 (2) provides that each Member of the Organization, which has ratified this Convention, shall establish 
and maintain a procedure which takes into account national conditions and needs and allows for a review of the minimum wage of groups of persons employed from time to time. The procedure for setting the minimum wage can take various forms, such as setting the minimum wage by: a) legislation; $b$ ) decisions of the competent authority with or without the inclusion of a formal provision to take into account recommendations from other authorities; c) decisions of wage councils or commissions; d) decisions of industrial or labor courts or tribunals; e) the entry into force of the provisions of the collective agreement.

In Art. 4 of the European Social Charter (revised) of 03 May 1996 (4) was proclaimed the right to fair remuneration. According to the Law of Ukraine "On Ratification of the European Social Charter (revised)" of September 14, 2006 No. 137-V (5), Ukraine has undertaken to consider subpara. 2, 3, 4, 5 of art. 4 of the European Social Charter (revised). At the same time, Ukraine has so far not undertaken obligations under paragraph 1 of Art. 4 " To recognize the right of workers to such remuneration as provides them and their families with a sufficient standard of living" of the European Social Charter (revised).

Among the acts of national legislation should be mentioned first of all the Constitution of Ukraine (6), as well as the Code of Laws on Labor of Ukraine (7), the Law of Ukraine "On Remuneration for Work" of March 24, 1995 8108/95-VR (8). According to part 1 of Art. 95 of the Code of Laws on Labor of Ukraine (as amended by the Law of Ukraine "On Amendments to Certain Legislative Acts of Ukraine" of December 6, 2016 №1774-VIII (9) minimum wage is the statutory minimum wage for the employee's monthly (hourly) norm of labor. This definition differs from the previous definition of the minimum wage, enshrined in the previous version of the part 1 art. 95 of the Code of Laws on Labor of Ukraine (7), as the statutory amount of wages for simple, unskilled work, below which an employee cannot be paid for the employee's monthly, hourly norm of work (volume of work). Thus, the minimum wage in the modern sense is not equated with payment for simple, unskilled work.

Scientific and theoretical definitions of "minimum wage" usually coincide with its normative content and 
the minimum wage is defined as the statutory amount of money, not lower than the subsistence level, which is paid for simple, unskilled labor to the employee (Kaplina, 2009), or as a mandatory state social guarantee, which is the minimum amount of monetary payment to the employee for a monthly or hourly rate of work (volume of work) and is established for unskilled labor with proper performance of his duties under normal conditions (Vegera, 2014), or as a mandatory state minimum social guarantee in the field of wages, which is the amount of guaranteed cash benefits to the employee, not lower than the subsistence level, for a monthly or hourly rate (volume of work) and is set for simple, unskilled labor (Derevyanko, 2015). However, most of the scientific developments in the relevant field were carried out before the entry into force of the Law of Ukraine "On Amendments to Certain Legislative Acts of Ukraine" of December 6, 2016 №1774-VIII (9) and are currently not relevant.

The conditions for determining the amount of the minimum wage, the procedure for establishing and revising its amount are determined by Articles 9 and 10 of the Law of Ukraine "On Remuneration of Labor" of March 24,
1995 № 108/95-VR (8). This is expressly provided for in part 4 of Art. 95 of the Code of Laws on Labor (7), according to which the minimum wage is set and revised in accordance with Articles 9 and 10 of the Law of Ukraine "On Remuneration of Labor" of March 24, 1995 № 108/95-VR (8) and cannot be lower than the size of the subsistence minimum for able-bodied persons.

According to part 5 of Art. 95 of the Code of Laws on Labour of Ukraine minimum wage is a state social guarantee, mandatory throughout Ukraine for enterprises, institutions, organizations of all forms of ownership and management and individuals who use the labor of employees, under any system of remuneration. According to Art. 6 of the Law of Ukraine "On Remuneration of Labor" of March 24, 1995 № 108/95-VR (8) minimum wage is the basis for the formation and differentiation of wages in the field of wage system (the latter includes: tariff grids, tariff rates, salary schemes and professional standards (qualification characteristics). The main element of the modern tariff system of remuneration is the tariff grid (salary scheme), which is formed on the basis of the tariff rate of the worker of the first category and inter- 
qualification (inter-job) ratios of rates (salaries). In turn, the tariff rate of a worker of the first category (except for public sector employees) may not be lower than the statutory minimum wage.

The Law of Ukraine "On Amendments to Certain Legislative Acts of Ukraine" of December 6, 2016 №1774-VIII (9) supplemented the Law of Ukraine "On Remuneration of Labor" of March 24, 1995 № 108/95-VR (8) with Article 3-1 "Guarantees of ensuring the minimum wage", according to part 1 of which the amount of wages of the employee for a fully performed monthly (hourly) norm of work may not be lower than the amount of the minimum wage.

These guarantees apply to all employees, i.e. individuals who work on the basis of an employment agreement (and in cases provided by the law - a contract) at an enterprise, institution, organization or for an individual who uses hired labor.

According to the Law of Ukraine "On State Social Standards and State Social Guarantees" of October 5, 2000 № 2017-III (10), the minimum wage is referred to the main state social guarantees. According to Art. 1 of the Law of Ukraine "On State Social Standards and State Social Guarantees" of October 5, 2000 № 2017-III (10) state social guarantees are the statutory minimum wages, incomes, pensions, social assistance, other types of social benefits, established by laws and other regulations that ensure a standard of living not lower than the subsistence level.

According to part 1 of Art. 17 of the Law of Ukraine "On State Social Standards and State Social Guarantees" of October 5, 2000 № 2017-III (10) basic state social guarantees are established by laws in order to ensure the constitutional right of citizens to a sufficient standard of living. According to part 2 of Art. 17 of the Law of Ukraine "On State Social Standards and State Social Guarantees" of October 5, 2000 № 2017-III (10) the main state social guarantees include:

- minimum wage;

- minimum old-age pension;

- non-taxable minimum income of citizens;

- amounts of state social assistance and other social benefits.

Basic state social guarantees, which are the main source of existence, may not be lower than the subsistence level established by law (Part 3 of Article 17 of the Law of Ukraine "On State Social Standards and State Social 
Guarantees" of October 5, 2000 № 2017 III (10).

Thus, based on the provisions of the Law of Ukraine "On State Social Standards and State Social Guarantees" of October 5, 2000 № 2017-III (10), the subsistence level is the basic state social standard for determining the minimum wage as one of the main state social guarantees.

Part 1 of Art. 9 of the Law of Ukraine "On Remuneration of Labor" of March 24, 1995 № 108/95-VR (8) provides criteria for determining the amount of the minimum wage. This size is determined taking into account the needs of workers and their families, the value sufficient to ensure the proper functioning of the working person, maintaining his/her health, set of foods, minimum set of non-food items and the minimum set of services needed to meet basic social and cultural needs, as well as the general level of average wages, labor productivity and employment level.

Comparative legal analysis of the criteria for determining the amount of the minimum wage, enshrined in Art. 3 of the ILO Convention №131 (2), paragraph 3 of the ILO Recommendation №135 (3) and part 1 of Art. 9 of the Law of Ukraine "On Remuneration of Labor" of March 24, 1995 № 108/95-VR (8), gives grounds to conclude that the national legislation does not fully take into account international standards in this area. In particular, part 1 of Art. 9 of the Law of Ukraine "On Remuneration of Labor” of March 24, 1995 № 108/95VR (8) does not provide for such criteria as social benefits and needs for economic development in various industries: tourism (Tamosiuniene, Demianchuk, Koval, 2019; Koval et al., 2019), ecology (Koval, Mikhno, 2019; Koval et al., 2019; Gubanova et al., 2019), social sphere (Bukanov et al., 2019). It should also be noted that the ILO acts are not just about the level of employment, but about the "desirability of achieving and maintaining a high level of employment."

According to part 2 of Art. 9 of the Law of Ukraine "On Remuneration of Labor" of March 24, 1995 № 108/95VR (8) the minimum wage is fixed at an amount not less than the subsistence level for able-bodied persons.

According to part 5 of Art. 1 of the Law of Ukraine "On subsistence level" of July 15, 1999 № 966-XIV (11) subsistence level is a value sufficient to ensure the normal functioning of the human body, maintaining its health, set 
of foods (hereinafter - a set of foods), and also the minimum set of non-food products (hereinafter - a set of non-food products) and the minimum set of services (hereinafter - a set of services) necessary to meet the basic social and cultural needs of the individual. In the same sense, the term "subsistence level" is used in Art. 1 of the Law of Ukraine "On State Social Standards and State Social Guarantees" of October 5, 2000 № 2017-III (10).

The subsistence level belongs to the state social standards, which in Art. 1 of the Law of Ukraine "On State Social Standards and State Social Guarantees" of October 5, 2000 №2017-III (10) are defined as established by laws, other normative-legal acts, social norms and standards or their complex, on the basis of which the levels of basic state social guarantees are determined.

According to part 2 of Art. 2 of the Law of Ukraine "On State Social Standards and State Social Guarantees" of October 5, 2000 №2017-III (10) on the basis of social standards are determined the size of basic social guarantees: minimum wages and old-age pensions, other types of social benefits and assistance .
The Law of Ukraine "On State

Social Standards and State Social Guarantees” of October 5, 2000 №2017III (10) recognized the subsistence level as the basic state social standard. According to Art. 6 of this Law of Ukraine, the basic state social standard is the subsistence level established by law, which forms the ground for determination of the state social guarantees and standards in the areas of income of the population, housingcommunal, household, socio-cultural services, protection of health and education.

The Law of Ukraine "On State Social Standards and State Social Guarantees" of October 5, 2000 -2017III (10) also defines the areas of application of state social standards and norms and guarantees of their provision. In particular, in accordance with Art. 7 of the Law of Ukraine "On State Social Standards and State Social Guarantees" of October 5, 2000 №2017-III (10) state social standards in the field of income of the population are set in order to determine the size of state social guarantees in the field of wages, payments for compulsory state social insurance, the right to receive other types of social benefits and state social 
assistance and their amounts, as well as determining the priority of directions of state social policy.

The spheres of application of the subsistence minimum are defined in Art. 2 of the Law of Ukraine "On the subsistence minimum" of July 15, 1999 № 966-XIV (11). According to part 1 of Art. 2 of the Law of Ukraine "On the subsistence minimum" of July 15, 1999 № 966-XIV (11) the subsistence minimum is applied to:

- general assessment of the standard of living in Ukraine, which is the basis for the implementation of social policy and the development of certain state social programs;

- fixation of the size of the minimum wage and the minimum oldage pension, determination of the amount of social assistance, assistance to families with children, unemployment benefits, as well as scholarships and other social benefits based on the requirements of the Constitution of Ukraine and laws of Ukraine;

- determination of the right to receive social assistance;

- determination of state social guarantees and standards of service and security in the fields of health care,
380

education, social services (Bodnar, Mirkovich, Koval, 2019);

- setting the value of the tax-free

minimum income of citizens;

- formation of the State Budget

of Ukraine and of local budgets.

The Law of Ukraine "On Amendments to Certain Legislative Acts of Ukraine" of December 6, 2016 № 1774-VIII (9) enshrined the concept of "subsistence level established for ablebodied persons on January 1 of the calendar year" as a calculated value for calculating the salary of employees in the budget sphere only. The legitimate purpose of enshrining in the Law of Ukraine "On Amendments to Certain Legislative Acts of Ukraine" of December 6, 2016 № 1774-VIII (9) the category "subsistence level set for ablebodied persons on January 1 of the calendar year" as a calculated value for calculating the salary of employees exclusively in the budget sphere should be connected with two circumstances.

Firstly, before the adoption of the Law of Ukraine "On Amendments to Certain Legislative Acts of Ukraine" of December 6, 2016 № 1774-VIII (9) there were contradictions between part 6 of Art. 96 of the Code of Laws on Labor of Ukraine (7), part 6 of Art. 6 of the Law 
of Ukraine "On Remuneration of Labor" of March 24, 1995 № 108/95-VR (8) and part 4 of Art. 95 of the Code of Laws on Ukraine (7) and part 2 of Art. 9 of the Law of Ukraine "On Remuneration of Labor" of March 24, 1995 № 108/95-VR (8). In this regard, it was necessary to cite the provisions of part 3 of Art. 96 of the Code of Laws on Labor Ukraine (7) and part 6 of article 6 of the Law of Ukraine "On Remuneration of Labor" of March 24, 1995 № 108/95-VR (8), which provided for the minimum wage as the estimated value for calculating the salary, not the subsistence level, in accordance with the provisions of part 4 of Art. 95 of the Code of Laws on Labor of Ukraine (7), part 2 of Art. 9 of the Law of Ukraine "On Remuneration of Labor" of March 24, 1995 № 108/95-VR (8), which provide for the fixing of a minimum wage of not less than the subsistence level for able-bodied persons.

In addition, it was necessary to take into account the provisions of Articles 1, 2, 7 of the Law of Ukraine "On State Social Standards and State Social Guarantees" of October 5, 2000 №2017-III (10), in particular part 2 of Art. 2 of the said Law of Ukraine that on the basis of social standards the sizes of the basic social guarantees are defined: the minimum wage amount and that of the old-age pension, other types of social payments and support.

Therefore, based on the provisions of the Law of Ukraine "On State Social Standards and State Social Guarantees" of October 5, 2000 №2017III (10), the minimum salary as a state social guarantee should be determined on the basis of the subsistence level as a basic state social standard, and not the minimum wage, which is also a state social guarantee. That is, the state social guarantee (minimum salary) as the minimum wage for employees whose wages are paid in accordance with the resolution of the Cabinet of Ministers of Ukraine "On remuneration of employees on the basis of the Unified tariff grid of categories and coefficients of remuneration of employees of institutions budget sphere "of August 30, 2002 №1298 (12) cannot be determined on the basis of the same state social guarantee.

Secondly, regarding those employed exclusively in the budget sphere. Establishment of conditions and amounts of remuneration of employees of enterprises, institutions and organizations, financed or subsidized 
from the budget belongs to the sphere of state regulation of remuneration of labor. According to the part 1 of Art. 8 of the Law of Ukraine "On remuneration of labor" of March 24, 1995 № 108/95-VR (8) the state regulates the remuneration of employees of enterprises of all forms of ownership by setting the minimum wage and other state norms and guarantees, establishing conditions and amounts of remuneration of labor of managers of enterprises based on state, communal property, employees of enterprises, institutions and organizations financed or subsidized from the budget, as well as by taxation of employees' incomes. According to part 2 of Art. 8 of the Law of Ukraine "On Remuneration of Labor" of March 24, 1995 № 108/95-VR (8) the conditions of remuneration of employees of institutions and organizations financed from the budget are determined by the Cabinet of Ministers of Ukraine, except as provided in part 3 of this article, and part 1 of Art. 10 of this Law of Ukraine.

It should also be noted that the Law of Ukraine "On Amendments to Certain Legislative Acts of Ukraine" of December 6, 2016 № 1774-VIII (9) introduced the term "subsistence level established for able-bodied persons on
January 1 of the calendar year", although the Code of Laws on Labout of Ukraine (7), the Law of Ukraine "On State Social Standards and State Social Guarantees" of October 5, 2000 №2017-III (10), the Law of Ukraine "On Remuneration of Labor" of March 24, 1995 № 108/95-VR (8) mention the subsistence level for able-bodied persons without reference to a specific date, and which in accordance with Art. 7 of the Law of Ukraine "On the State Budget of Ukraine for 2020" of November 14, 2019 № 294-IX (13) is calculated per month from January 1, from July 1 and from December 1, 2020, respectively.

\section{Conclusion}

Thus, according to the laws of Ukraine, minimum wage is one of the main state social guarantees, mandatory throughout Ukraine for all employers under any wage system.

At the same time, the mechanism of fixing the minimum wage, enshrined in the current legislation of Ukraine, does not fully comply with international labor standards and practices of developed European countries. European practice shows that the level of the minimum wage is an 
important indicator not only of building a system of decent work, but also of socio-economic development of the country. Therefore, the adjustment of its size should take into account changes in prices and total incomes of the population in order to socially protect the lowest paid workers and ensure the stability of the tariff system, reduce the risk of inflationary pressures (Lopushnyak, 2017).

Today in Ukraine the level of wages does not provide a sufficient standard of living for workers and their family members. The size of the minimum wage remains the lowest in 2020 in comparison with the countries of the European Union, which Ukraine seeks to join (19). This is not consistent with the provisions of part 1 of article 17 of the Law of Ukraine "On State Social Standards and State Social Guarantees" of October 5, 2000 №2017-III (10) that the basic state social guarantees are established by laws in order to ensure the constitutional right of citizens to a sufficient standard of living.

In 2020 , the minimum wage in Ukraine increased by $13.2 \%$, in the ranking of growth of minimum wages among the world, Ukraine ranked 15th out of 54 countries (17). However, the mechanism for determining the amount of the minimum wage provided by the laws of Ukraine, does not allow to achieve the goals of its establishment, the way they are enshrined in ILO Convention №131 (2) and ILO Recommendation №135 (3).

\section{References}

Bodnar, S., Mirkovich, I., Koval, V. (2019). Human capital development in Ukrainian education system by means of language integrated teaching. Dilemas contemporaneos-educacion politica $\mathrm{y}$ valores, 7 (SI), 14.

Borychenko, K., Hudz, A., Koval, V., Golubkova, I., Mazur, A. (2019). European standards for social protection of internally displaced persons. Dilemas contemporaneos-educacion politica $\mathrm{y}$ valores, 7 (SI), 88 .

Bukanov H., Kolesnyk A., Tashkinova O., Kotlubai V., Koval V. (2019). Social marketing in public administration of social service institutions. Revista Genero \& Direito, 8 (6), 457-468.

Cabinet of Ministers of Ukraine (2002). On remuneration of employees on the basis of the Unified tariff grid of categories and coefficients for remuneration of employees of 
institutions, establishments and https://www.eurointegration.com.ua/ne organizations of certain branches of the budget sphere: Resolution of the Cabinet of Ministers of Ukraine of August 30, №1298. Official Herald of Ukraine. 2002. № 36. Art. 1699

Derevyanko, M.I. (2015). Minimum wage as a guarantee in the field of labor relations. Scientific Bulletin of the Academy of Municipal Administration: Series "LAW", 1, 153-158.

Dovbysh, K.K. (2017). Principles of legal regulation of wages. Dissertation for the candidate of juridical sciences degree in the specialty 12.00.05, Yaroslav the Wise National Juridical University. Retrived from http://nauka.nlu.edu.ua/download/diss/

DovbishO/d_DovbishO.pdf

Ekonomichna Pravda (2020). Rating of growth of minimum wages in the world: Ukraine in 15th place. Retrived from https://www.althoughda.com.ua/news/2 020/01/14/655766/

European Social Charter (2007). Information of the Verkhovna Rada of Ukraine, № 51, 2096.

Evropeyska Pravda (2020). Minimum wage in the EU: the lowest in Bulgaria, the highest - in Luxembourg. Retrived from

ws/2020/02/4/7105948/

Gubanova E., Kupinets L., Deforzh H., Koval V., Gaska K. (2019). Recycling of polymer waste in the context of developing circular economy. Architecture Civil Engineering Environment, 12(4), 99-108. doi: 10.21307/ACEE-2019-055

International Labour Organization (1999). Minimum Wage Fixing Convention No. 131, with Special Account for Developing Countries, 1970. Conventions and recommendations adopted by the International Labor Organization. 19651999. Volume II. Geneva: International Labor Office.

International Labour Organization (1999). Minimum Wage Fixing Machinery Convention No. 26 of 1928. Conventions and recommendations adopted by the International Labor Organization. 1919-1964. Volume I. Geneva: International Labor Office.

International Labour Organization (1999). Minimum Wage Fixing Recommendation, 1970 (No. 135) with special regard to developing countries. Conventions and recommendations adopted by the International Labor 
Organization. 1965-1999. Volume II. Geneva: International Labor Office.

Kaplina, G.A. (2009). Problems of legal regulation of wages in market conditions of Ukraine and ways of its improvement [Dissertation for the candidate of juridical sciences degree in the specialty 12.00.05, V. Dalya East Ukrainian National University]. V. Dalya Institutional Repository of East Ukrainian National University.

Koval, V., Mikhno I. (2019). Ecological sustainability preservation of national economy by waste management methods. Economics. Ecology. Socium, 3(2), 30-40.

Koval, V., Mykhno, Y., Antonova, L., Plekhanov, D., \& Bondar, V. (2019). Analysis of environmental factors' effect on the development of tourism. Journal of Geology, Geography and Geoecology, 28(3), 445-456.

Koval, V., Petrashevska, A., Popova, O., Mikhno, I., \& Gaska, K. (2019). Methodology of ecodiagnostics on the example of rural areas. Architecture Civil Engineering Environment, 12(1), 139-144.

Lopushnyak, G.S. (2017). Minimum wage: the practice of Ukraine and the experience of the European Union.
Demography and social economy, 1, 132-144.

Nazarova, K., Hordopolov, V., Kopotiienko, T., Miniailo, V., Koval, V., \& Diachenko, Y. (2019). Audit in the state economic security system. Management Theory and Studies for Rural Business and Infrastructure Development, 41(3), 419-430.

On ratification of the European Social Charter (2006). Law of Ukraine of September 14, 2006 No. 137-V. Information of the Verkhovna Rada of Ukraine, № 43, Art. 418.

Popova, O., Koval, V., Antonova, L., \& Orel, A. (2019). Corporate social responsibility of agricultural enterprises according to their economic status. Management Theory and Studies for Rural Business and Infrastructure Development, 41(2), 277-289. https://doi.org/10.15544/mts.2019.23

Tamosiuniene, R., Demianchuk, M., Koval, V. (2019). State Regulation of Bankruptcy Relations in the National Economy. Economics. Ecology. Socium, 3 (4), 19-27. Vegera, V.M. (2014). Minimum wage fixing as a way of state regulation of wages in Ukraine. Dissertation for the candidate of juridical sciences degree in 
the specialty 12.00 .05 , Taras Shevchenko Kyiv National University. Vegera, V.M. (2014). Regarding the definition of "minimum wage". Scientific Bulletin of Kherson state university. Ser. Jurid. Science, 2, 88-92. Verkhovna Rada of Ukraine (1971). Code of Labor Laws of Ukraine: Approved by the Law of the USSR of December 10, 1971 №322-VIII. Information of the Verkhovna Rada of the USSR. Supplement to №50. Art. 375. Verkhovna Rada of Ukraine (1995). On remuneration of labor: Law of Ukraine of March 24, 1995 № 108/95-VR. Information of the Verkhovna Rada of Ukraine, №17. Art. 121.

Verkhovna Rada of Ukraine (1996). The Constitution of Ukraine, adopted at the fifth session of the Verkhovna Rada of Ukraine on June 28, 1996. Information of the Verkhovna Rada of Ukraine, №30. Art. 141.

Verkhovna Rada of Ukraine (1999). On the subsistence level: Law of Ukraine of July 15, 1999 №966-XIV. Information of the Verkhovna Rada of Ukraine, № 38. Art. 348 .

Verkhovna Rada of Ukraine (2000). On state social standards and state social guarantees: Law of Ukraine of October 5, 2000 № 2017-III. Information of the
Verkhovna Rada of Ukraine, № 48. Art. 409.

Verkhovna Rada of Ukraine (2017). On amendments to some legislative acts of Ukraine: Law of Ukraine of December 6, 2016 № 1774-VIII. Information of the Verkhovna Rada of Ukraine, № 2. Art. 25.

Verkhovna Rada of Ukraine (2020). On the State Budget of Ukraine for 2020: Law of Ukraine of November 14, 2019 № 294-IX. Information of the Verkhovna Rada of Ukraine, № 5, Art. 31.

Yankovyi O., Koval V., Trokhymets O., Karpenko M., Matskevich Y. (2020). Economic assessment of investment on the basis of production functions. Turismo: Estudos \& Práticas, 2 